\title{
Elucidation of the Disease Cycle of Olive Anthracnose Caused by Colletotrichum acutatum
}

\author{
Juan Moral, Rodrígues de Oliveira, and Antonio Trapero
}

First and third authors: Departamento de Agronomía, ETSIAM, Universidad de Córdoba, Campus de Rabanales, Edif. C4, 14071 Córdoba, Spain; and second author: Faculdade de Ciências Agrarias, Universidade Agostinho Neto, 236 Huambo, Angola. Accepted for publication 17 December 2008.

\begin{abstract}
Moral, J., Oliveira, R., and Trapero, A. 2009. Elucidation of the disease cycle of olive anthracnose caused by Colletotrichum acutatum. Phytopathology 99:548-556.

Anthracnose, caused by Colletotrichum acutatum and C. gloeosporioides, is a major fungal disease of olive in many countries. In Spain, the disease has been associated only with a characteristic rot and mummification of mature fruit. The purpose of this study was to determine whether $C$. acutatum could infect other plant tissues that may serve as sources of inoculum for anthracnose epidemics. Inoculations of young plants or detached leaves and field observations demonstrated that flowers and immature olive fruit are susceptible to the pathogen. Flower infection caused blight of inflorescences and infection of developing fruit.

Plants without fruit were infected but they did not show any disease symptoms. Only plants with rotten fruit developed leaf wilting and branch dieback symptoms several weeks later. These results, together with the low level of pathogen isolation from affected leaves and branches and the toxicity of sterile fungal extracts to olive cuttings, suggest that a toxic substance produced by $C$. acutatum in rotten fruit may account for this syndrome. Both disease syndromes, fruit rot and branch dieback, developed in several olive cultivars, which were equally susceptible to the pathogen. However, olive cultivars differed in their response to flower and fruit infection. Latent infection of developing fruit during the spring may permit survival of the pathogen during the hot and dry summer and serve as an inoculum source for anthracnose epidemics that develop on ripening fruit in autumn.
\end{abstract} Immature fruit were infected in all phenological stages, although infection remained latent for 7 to 8 months, until the onset of fruit ripening. Fruit susceptibility increased and latent period decreased with maturity. Fruit were required for symptom development on inoculated plants.
Additional keywords: aceituna jabonosa, Gloeosporium olivarum, Olea europaea.
Species of Colletotrichum collectively cause anthracnose on olive (Olea europaea L.), which is considered the most important fruit disease of this crop worldwide $(19,25,51,53)$. Under favorable environmental conditions, the disease can devastate entire production fields $(25,51,53)$. In Spain, the overall loss in net income for the olive industry caused by Colletotrichum spp. is over $\$ 93.4$ million per annum $(19,30)$.

In Spain, disease symptoms have been noted only in fruit (fruit rot [soapy fruit] and mummification) $(19,20,37,39)$; although, in recent epidemics, affected trees also showed defoliation and dieback of shoots and branches $(53,54)$. In other countries, such as Greece, Italy, and Portugal, infections of leaves, shoots, and branches are common $(17,25,33,51,57)$.

Olive anthracnose is caused by the fungal pathogens Colletotrichum acutatum J. H. Simmonds and C. gloeosporioides (Penz.) Penz. \& Sacc. $(35,36,51)$. Previous research in Greece, Italy, and Spain identified C. gloeosporioides (originally: Gloeosporium olivarum) as the primary cause of olive anthracnose $(33,37,57)$. However, recent investigations have shown that $C$. acutatum is the dominant species in olive fields in Spain and Portugal and that both species can cause anthracnose $(35,36,51)$. Even so, isolates of olive anthracnose with morphological and physiological characteristics of both species have been observed in Spain and Italy $(3,42)$.

As in other pathosystems (43), much of the research in recent years has been dedicated to elucidate the etiology of olive an-

Corresponding author: A. Trapero; E-mail address: trapero@uco.es

doi:10.1094/PHYTO-99-5-0548

(C) 2009 The American Phytopathological Society thracnose $(4,28,35,36,51)$. Less effort has been dedicated to determining the life cycle of Colletotrichum spp. in olive $(33,37)$. In addition, some of these studies have been carried out under weather conditions very different from the Mediterranean climate (27). Most importantly, the Mediterranean basin is the world's largest producer and center of diversity of olive (12) and, therefore, studies on anthracnose need to focus on olive grown in this area.

The life cycle of Colletotrichum spp. in olive is not well known. Mateo-Sagasta (37) indicated that the fungus might survive in mummified fruit on the soil surface. Other researchers indicated that the fungus survives in mummified fruit on the tree, because mummified fruit on the soil surface are buried by soil cultivation or destroyed by insects and secondary invaders (25). Therefore, conidia from mummified fruit that are dispersed during the fall when the fruit begin to ripen were considered the primary inoculum of olive anthracnose $(19,20,33,37,53)$. In other tree crops, such as avocado (14), citrus (15), apple (13), blueberry (55), and mango (7), infection by Colletotrichum spp. can take place at all stages of fruit development, although infection remains latent until the onset of ripening. Based on what is known for the olive anthracnose cycle, the initial fruit infection occurs during the fall $(33,37)$. However, the importance of latent infection in developing fruit is poorly understood $(2,21)$ and could play an important role in olive anthracnose.

The role of epiphytic stages or latent infections of Colletotrichum spp. on leaves, shoots, and branches is not clear in olive anthracnose. The pathogen can be isolated from all these symptomless tissues but, under field conditions in Spain, no acervuli or conidial masses have been observed on these tissues (J. Moral and A. Trapero, unpublished data). In contrast, acervuli have been observed in symptomatic leaves in Greece and Italy $(34,57)$. 
A better understanding of the biology and epidemiology of the disease could improve management decisions, such as the timing of fungicide applications. Consequently, the main objective of this study was to better understand the epidemiology of olive anthracnose by evaluating the susceptibility of flowers, developing fruit, leaves, and shoots to infection by $C$. acutatum under artificial and natural conditions. The main conclusions of this research are that olive flowers and developing fruit can be infected during the spring and are important sources of inoculum for fruit rot epidemics that occur in the autumn. In contrast, leaf wilting and branch dieback are secondary symptoms occurring after fruit rot development. A preliminary report of this study has been published (40).

\section{MATERIALS AND METHODS}

Olive plants. Potted olive plants (2 to 4 years old) of three olive cultivars were grown in 7-liter plastic containers. Cvs. Arbequina, Hojiblanca, and Picual are generally considered to be susceptible, moderately susceptible, and resistant to anthracnose, respectively $(38,39)$. These cultivars are extensively grown throughout Spain (10). Potted plants were grown at $19-30^{\circ} \mathrm{C}$ in a closed greenhouse located far from most inoculum sources of Colletotrichum spp. Plants were fertilized once $\left(7 \mathrm{~g}\right.$ of $\mathrm{P}_{2} \mathrm{O}_{5}+2 \mathrm{~g}$ of $\mathrm{NO}_{3} \mathrm{~K}+1 \mathrm{~g}$ of $\mathrm{CO}_{3} \mathrm{Ca}+1 \mathrm{~g}$ of $\mathrm{SO}_{4} \mathrm{Mg}+0.6 \mathrm{~g}$ of $\mathrm{CO}_{3} \mathrm{Mg}$ per plant) and irrigated as needed.

Fungal isolates. All isolates of Colletotrichum spp. were collected from olive trees showing fruit rot in commercial plantings in the Andalusia region of southern Spain. Five isolates (Col-9, Col-10, Col-30, Col-57, and Col-87) were used in inoculation experiments. These isolates exhibited morphological and physiological characteristics intermediate between $C$. gloeosporioides and $C$. acutatum, except Col-30, which showed morphological characteristics of C. gloeosporioides (42). All isolates were identified as $C$. acutatum because their internal transcribed spacer (ITS) and 5.8S region of rDNA showed complete homology with the reference isolate IMI-351255 of C. acutatum (unpublished data). These isolates are representative of the Spanish population of Colletotrichum spp. pathogenic to olive trees (42). Single-spore isolates were cultured in petri dishes containing potato dextrose agar (PDA) (Difco Laboratories, Detroit) acidified with lactic acid $(2.5 \mathrm{ml}$ of a $25 \%$ [vol/vol] per liter of medium). Petri dishes were incubated at $23 \pm 2{ }^{\circ} \mathrm{C}$ with a 12-h photoperiod of fluorescent light $\left(40 \mu \mathrm{mol} \mathrm{m} \mathrm{m}^{-2} \mathrm{~s}^{-1}\right)$ for 1 week. To ensure that the conidia used were viable, germination of each batch of inoculum was measured prior to each inoculation. Inoculum density of $C$. acutatum was measured with a hemacytometer and diluted to $10^{6}$ or $5 \times 10^{5}$ conidia $/ \mathrm{ml}$, depending on the experiment.

Inoculation and incubation. Plants were sprayed to run-off with a conidial suspension at different flowering and fruiting phenological stages (48), depending on the experiment. In all experiments, the same number of noninoculated plants was sprayed similarly with sterile water and used as controls. After inoculation, inoculated and control plants were covered with a $1-\mathrm{m}^{3}$ plastic bag, incubated in a growth chamber at $23 \pm 2^{\circ} \mathrm{C}$ for $48 \mathrm{~h}$ in the dark, and then transferred to the greenhouse at $19-30^{\circ} \mathrm{C}$ for symptom development.

Determination of latent infections in fruit and isolation of the pathogen from different olive tissues. The number of fruit with latent infections of Colletotrichum spp. was determined using the herbicide $\mathrm{N}, \mathrm{N}^{\prime}$-dimethyl-4,4'-bipyridinium dichloride (Paraquat) $(13,42)$. For each sample, fruit were washed with sterile distilled water for $30 \mathrm{~min}$, surface disinfested by successive immersion in $70 \%$ ethanol for 2 min and in a $20 \%$ solution of commercial bleach $(\mathrm{Cl}$ at $50 \mathrm{~g} /$ liter $)$ in sterile water for $7 \mathrm{~min}$, and dipped in Paraquat (Paratex, 200 g/liter; Aragonesas Agro S.A., Madrid, Spain) at $2.9 \mathrm{~g} / \mathrm{liter}$ of water for $1 \mathrm{~min}$. The entire process was conducted in a gas-negative suction hood. Treated fruit were incubated over sterile humid perlite in closed $(100 \%$ relative humidity $[\mathrm{RH}]$ ) plastic containers and placed in a growth chamber kept at $23 \pm 2{ }^{\circ} \mathrm{C}$ in the dark for 21 days. The incidence of fruit with latent infections was calculated as the percentage of fruit that showed typical anthracnose symptoms (visible orange sporulation) with respect to the total number of treated fruit. To evaluate the presence of Colletotrichum spp. in olive samples from different symptomless tissues, small tissue pieces $\left(\approx 4 \mathrm{~mm}^{2}\right)$ from leaves, shoots, and branches were cultured in petri dishes containing acidified PDA plus copper sulfate (APDA+Cu) (Merck, Darmstadt, Germany) at $100 \mathrm{mg} /$ liter of medium (6). Petri dishes were incubated at $23 \pm 2{ }^{\circ} \mathrm{C}$ with a 12-h photoperiod of fluorescent light $\left(40 \mu \mathrm{mol} \mathrm{m} \mathrm{m}^{-2} \mathrm{~s}^{-1}\right)$ for 1 week. After incubation, both number of pieces with Colletotrichum spp. and the percentage of olive tissues with Colletotrichum spp. were recorded. The percent recovery of Colletotrichum spp. was calculated for each sample from all tissue pieces plated.

Susceptibility of leaves, shoots, and branches. In fall 2000, 2-year-old plants of cvs. Hojiblanca and Picual with leaves of various ages and without fruit were sprayed with a suspension of isolates Col-10 or Col-30 at $10^{6}$ conidia/ml. A factorial combination (two by two) of treatments was arranged in a completely randomized design. There were five replicate plants per treatment and the experiment was performed twice. The inoculated and control plants were incubated as described above. Plants were assessed periodically for aerial symptoms for 8 months. The presence of $C$. acutatum was monitored twice, 40 days and 8 months after inoculation. Each time, 100 small pieces of leaf and shoot tissue were placed on APDA+Cu as described above. In a different trial, detached leaves of cvs. Hojiblanca and Picual were inoculated by injection in the central vein with $4 \mu$ of a conidial suspension $(5 \times$ $10^{5}$ conidia/ml) of isolate Col-9 of $C$. acutatum using a $0.5-\mathrm{mm}-$ wide sterile needle. Before inoculation, leaves were washed in sterile water for $45 \mathrm{~min}$, surface disinfested in a $10 \%$ solution of bleach $(\mathrm{Cl}$ at $50 \mathrm{~g} / \mathrm{liter})$ for $1 \mathrm{~min}$, washed again with sterile water, and then allowed to air dry on a laboratory bench. Inoculated and control leaves were incubated at $23 \pm 2{ }^{\circ} \mathrm{C}$ with 12-h photoperiod of fluorescent light $\left(40 \mu \mathrm{mol} \mathrm{m} \mathrm{m}^{-2} \mathrm{~s}^{-1}\right)$ in humid $(100 \%$ $\mathrm{RH})$ chambers for 21 days. Disease severity was assessed periodically for the presence of symptoms in the leaves. A completely randomized design with three replicated humid chambers and 24 leaves per replicate was used and the experiment was performed twice. The presence of $C$. acutatum in all inoculated and control leaves was recorded 21 days after inoculation using APDA+Cu as mentioned above.

Comparative susceptibility of plants with and without fruit. During fall-winter 2001, 3-year-old plants with and without fruit of cvs. Hojiblanca and Picual were sprayed with a suspension of isolates Col-10 or Col-30 at $10^{6}$ conidia/ml. There were five replicate plants with fruit and five without fruit for each cultivar and isolate. The experiment was conducted twice, in November (fruit coloring) and December (harvest ripening). The factorial combination (two by two) of treatments was arranged in a completely randomized design. The inoculated and control plants were incubated as described above. Leaves and shoots were assessed for typical anthracnose symptoms. The affected fruit were assessed weekly for symptoms using a previously described severity scale from 0 to 5 (39) for 1 month after the first symptoms appeared. The disease index (DI) and the relative area under the disease progress curve (RAUDPC) were calculated for each replicate (39). Data of RAUDPC were subjected to analysis of variance (ANOVA) and means were compared with the Fisher's protected least significant difference (LSD) test at $P=0.05$ (50). Data from all experiments were analyzed using Statistix 9 (Analytical Software, Tallahassee, FL). The presence of $C$. acutatum in 100 leaves and shoots of each cultivar was assessed 21 days after inoculation using APDA+Cu as described above. 
Susceptibility of developing fruit. During 2000, 3-year-old plants of cv. Hojiblanca with fruit were sprayed with a suspension of C. acutatum at $10^{6}$ conidia/ml. Plants were inoculated monthly at different phenological growth stages (48): fruit at $\approx 10,20$, and $50 \%$ of their final size (15 June, 15 July, and 15 August, respectively); fruit showing a deep green color becoming light green or yellowish (15 September); fruit with beginning of coloring (15 October); fruit with increasing coloring (15 November); and fruit at harvest ripening (15 December). There were five replicate plants for each inoculation date. The experiment was conducted twice with both Col-09 and Col-10 isolates. The data presented are the averages of the two experiments because error variances were homogeneous and ANOVA did not show significant differences between isolates. Incidence (\%) of infected fruit 1 month after the first symptoms appeared and average latent period (in days) were assessed for each plant. Severity of infection (DI and RAUDPC) was also calculated as described above. Data showing the effect of inoculation time on RAUDPC were subjected to ANOVA and means were compared by Fisher's protected LSD test at $P=0.05$. Nonlinear regression analysis was used to study the relationship between average latent period (in days) and inoculation time (days after full bloom) in each plant. Goodness of fit was evaluated by modifying Akaike's information criterion using Statistix9, coefficient of determination $\left(R^{2}\right)$, normal distribution of errors, and residual plots (31).

In the spring of 2005, 3-year-old plants of cvs. Arbequina, Hojiblanca, and Picual were sprayed with a conidial suspension of isolate Col-87 at $10^{6}$ conidia/ml to study the influence of $C$. acutatum infection in the fall on developing fruit. To promote fruit set inside the greenhouse and before inoculation, plants were pollinated during full bloom ( $>50 \%$ open flowers) with a pollen mixture (1:1:1, vol/vol/vol) from cvs. Hojiblanca, Picual, and Frantoio. Plants were inoculated in June (fruit set) and incubated as described above. Seven pairs of plants were selected based on the number of fruit before inoculation (initial fruit). For each pair of plants, one was inoculated with the pathogen and the other was treated with water (control plant). The total number of fruit per plant, fruit with visible symptoms, and fruit ripening (color class from 0 to 4) (11) were assessed periodically for 9 months. Nonfertilized ovaries, similar to small fruit (less than $3 \mathrm{~mm}$ in diameter), were not included in the observations. The percentage of fallen fruit (FF) with respect to initial fruit, incidence (\%) of fruit with anthracnose symptoms, and average fruit maturity were calculated for each plant. The area under the FF curve (AUFFC) was determined. Wilting, defoliation, and dieback of branches (DB) was assessed at the end of the experiment (218 days after inoculation) by using a 0 -to- 5 scale $(0=$ no visible symptoms, $1=$ visible symptoms affecting $<25 \%$ of the plant canopy, $2=25$ to $50 \%, 3=50$ to $75 \%, 4=>75 \%$, and $5=$ dead plant). The experiment was repeated with similar results; therefore, the results of both experiments were combined. Data were tested for normality by the Shapiro-Wilk's test and the AUFFC of inoculated and control plants were compared by paired $t$ tests. DB was subjected to ANOVA and means were compared by Fisher's protected LSD at $P=0.05$. Linear regression analysis was used to evaluate the relationships between fruit ripening (color class) and the percentage of affected fruit for each cultivar. Comparison of the regression lines among cultivars was made, taking into consideration the homogeneity of variances, slopes, and elevations. In both trials, presence of $C$. acutatum in 100 leaves and shoots of both cultivars was assessed 21 days after inoculation by culturing of plant tissues on APDA+Cu as described above. All fruit of the three cultivars that did not show anthracnose symptoms were tested for latent infection by the Paraquat method.

Susceptibility of inflorescences. In spring 2004, 3-year-old plants of cv. Hojiblanca were sprayed with a suspension of isolate Col-57 at $10^{6}$ conidia/ml. Plants were pollinated $48 \mathrm{~h}$ before inoculation and incubated as described above. Plants were then inoculated during two different flowering stages (48), such as at the beginning $(<10 \%$ of flowers open) and full flowering $(>50 \%$ of flowers open). The full factorial combination of treatments (two flowering stages and inoculated and control plants) was arranged in a completely randomized design with five replicate plants per inoculation time. The experiment was conducted twice. The data presented are the average of the two experiments because error variances were homogeneous and ANOVA did not show significant differences between experiments. Severity of infection was assessed 3 months after inoculation by the fruit set (FS $=$ [number of fruit at each time/number of initial inflorescences] $\times 100)$ and by incidence $(\%)$ of fruit with visible disease symptoms. ANOVA was performed on the FS data and treatment means were compared by the Fisher's protected LSD test at $P=$ 0.05 .

In spring 2005, 3-year-old plants of cvs. Arbequina, Hojiblanca, and Picual were inoculated by spraying with a suspension of isolate Col-87 at $10^{6}$ conidia $/ \mathrm{ml}$. Plants were pollinated at full bloom and incubated as described above. Seven pairs of plants were selected based on the number of inflorescences before inoculation (initial inflorescences). For each pair, one plant was inoculated and the other was treated with water. During the next 9 months, the total number of fruit, fruit with visible symptoms, and fruit ripening ( 0 to 4 ) of each plant was recorded periodically. The FS, percentage of fruit with visible symptoms, and average of fruit maturity were calculated for each plant. The area under the FS curve (AUFSC) was determined. The experiment was repeated with similar results and the results of both experiments are reported together. The FS and AUFSC data of inoculated and control plants were compared by the Wilcoxon signed rank test. In both years, the presence of $C$. acutatum in 100 leaves and shoots of each cultivar was assessed 21 days after inoculation by culturing of plant tissues on APDA+Cu as described above. All fruit of the three cultivars that did not show anthracnose symptoms were tested for latent infection by the Paraquat method.

Natural infection of inflorescences, developing fruit, leaves, and branches. The population of Colletotrichum spp. on different olive tissues was assessed under field conditions at different times and years. Olive tissues were harvested from different orchards where anthracnose is endemic in Andalusia (southern Spain) (Table 1). All trees were grown according to the farmer's usual practices, including the application of copper fungicide in the spring and fall to control foliar diseases (46). Small pieces of inflorescences, leaves, shoots, and branches were cultured on $\mathrm{APDA}+\mathrm{Cu}$ to detect Colletotrichum spp. The sample size of each tissue at each location is given in Table 1. Again, the Paraquat method was used to detect latent infections of the fungus on developing fruit.

Toxicity of cultural filtrates. Two different trials were conducted to evaluate phytotoxin production by one olive isolate of C. acutatum from Spain. In the first trial, modified liquid Richards' medium $\left(\mathrm{KNO}_{3}, 10 \mathrm{~g} ; \mathrm{KH}_{2} \mathrm{PO}_{4}, 5 \mathrm{~g} ; \mathrm{MgSO}_{4} \cdot 7 \mathrm{H}_{2} \mathrm{O}\right.$, $2,5 \mathrm{~g} ; \mathrm{FeCl}_{3}, 5 \mathrm{mg}$; sucrose, $50 \mathrm{~g}$; and distilled water, 1 liter) was used (56). A small mycelial block of agar (10 $\mathrm{mm}$ in diameter) of isolate Col-9 harvested from a 7-day-old PDA dish was transferred to $90 \mathrm{ml}$ of Richards' medium in 250-ml Erlenmeyer flasks. Inoculated flasks were incubated subsequently at $22^{\circ} \mathrm{C}$ with a $12-\mathrm{h}$ photoperiod of fluorescent light $\left(40 \mu \mathrm{mol} \mathrm{m}^{-2} \mathrm{~s}^{-1}\right)$ and placed on a rotary shaker at $150 \mathrm{rpm}$ for 10 days. The cultural filtrate was obtained by filtering the liquid medium with the fungus through a sterile filter paper to remove mycelia; second, through a $1.2-\mu \mathrm{m}$ sterile nitrocellulose acetate membrane (Millipore; Bedford, MA); and, finally, through a $0.2-\mu \mathrm{m}$ sterile cellulose acetate membrane (Albet; Barcelona, Spain) to prevent spore contamination. Ninemonth-old olive stem cuttings of cvs. Hojiblanca and Picual with five pairs of leaves from a nursery hedge were placed in test tubes containing $25 \mathrm{ml}$ of fungal culture filtrate. Three additional treatments were used: sterile water, liquid Richards' medium, and a 
suspension of the fungus $\left(10^{6}\right.$ conidia/ml $)$. Six stem cuttings were tested in a factorial combination (four by two) of treatments in a completely randomized design. Foliar symptoms were recorded at 7 days using the following scale: $0=$ no symptoms, $1=$ slight symptom development (1-33\% foliage affected), $2=$ moderate symptom development (34-66\% foliage affected), $3=$ heavy symptom development (67-100\% foliage affected), and $4=100 \%$ foliage affected with defoliation or dead stem cutting. The experiment was repeated once without significant differences. The same trial was repeated but liquid Richards' media was replaced by liquid potato dextrose (PD) medium and the severity of symptoms was recorded 7 and 14 days after inoculation. Data were analyzed using the Kruskal-Wallis nonparametric test and means were compared at $P=0.05$ (Analytical Software).

\section{RESULTS}

Susceptibility of leaves, shoots, and branches. Two-year-old plants inoculated with $C$. acutatum were infected but they did not develop symptoms at the end of the experiment. Only Picual plants showed a slight apical necrosis of young shoots 14 days after inoculation; however, these plants continued growing and did not show visible symptoms 2 months after inoculation. The pathogen was isolated from $\approx 90 \%$ of leaves and shoots 40 days after inoculation and from 38.6 and $16.7 \%$ of leaves and shoots, respectively, 8 months after inoculation. $C$. acutatum did not develop conidiomata (acervuli) or conidial masses on the leaves or shoots, even when inoculated tissues were incubated in humid chambers.

Separate leaves inoculated by injection only showed small brown spots, and no acervuli or conidia were observed. The pathogen was not isolated from inoculated and control leaves inoculated by injection 21 days after inoculation.

Comparative susceptibility of plants with and without fruit. Only inoculated plants of cv. Hojiblanca with fruit showed anthracnose symptoms, including soapy rot, mummification, and premature fruit drop. Subsequently, a second set of symptoms developed that began as a drying of leaves and evolved into dieback of shoots and branches. Plants of Picual with and without fruit, Hojiblanca without fruit, and control plants did not show any symptoms. Isolate Col-09 was more virulent than isolate Col30 when inoculations were done in November but there was no significant differences between the isolates when inoculated in December $(P<0.05)$ (Fig. 1). The pathogen developed conidiomata (acervuli) or conidial masses only on infected fruit of cv. Hojiblanca. However, C. acutatum was isolated from leaves and shoots of all inoculated plants. The percentages of isolation were 24.5 and $11 \%$ of symptomatic and nonsymptomatic Hojiblanca leaves; 6.3 and $3.75 \%$ of symptomatic and nonsymptomatic Hojiblanca shoots; and 0.75 and $4.35 \%$ of nonsymptomatic Picual leaves and shoots, respectively.

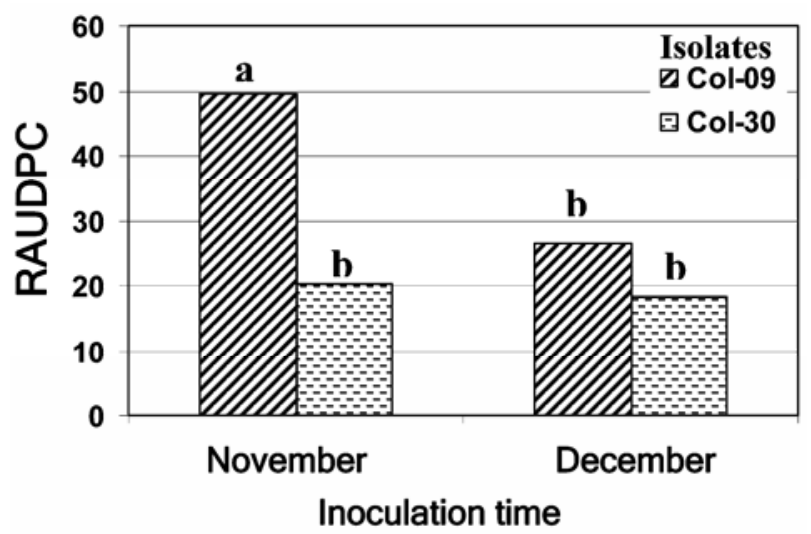

Fig. 1. Relative area under the disease progress curve (RAUDPC) in olive plants of cv. Hojiblanca inoculated with isolates Col-09 or Col-30 of Colletotrichum acutatum. Bars are mean values of 10 plants for each isolate. For each inoculation time, bars with the same letter are not significantly different according to Fisher's protected least significant difference at $P=0.05$.

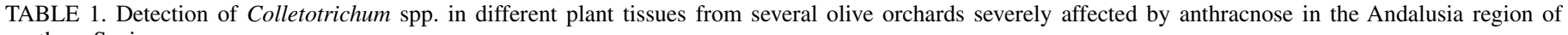
southern Spain

\begin{tabular}{|c|c|c|c|c|}
\hline Plant tissue, symptom, cultivar & Month, year & Orchard, province & No. of samples & Detection of Colletotrichum spp. (\%) \\
\hline \multicolumn{5}{|l|}{ Branch $^{y}$} \\
\hline Dead branch, Picudo & January 2008 & La Fuente Rosa, Córdoba & 150 & 0.0 \\
\hline Dead branch, Picudo & February 2007 & La Fuente Rosa, Córdoba & 150 & 0.0 \\
\hline \multicolumn{5}{|l|}{ Inflorescencey } \\
\hline Blighted, Hojiblanca & May 2006 & La Mina, Córdoba & 100 & 1.0 \\
\hline Blighted, Hojiblanca & May 2007 & La Mina, Córdoba & 100 & 3.0 \\
\hline \multicolumn{5}{|l|}{ Leaf ${ }^{y}$} \\
\hline No symptoms, Hojiblanca & June 2007 & La Mina, Córdoba & 100 & 0.0 \\
\hline No symptoms, Hojiblanca & July 2007 & La Mina, Córdoba & 100 & 1.67 \\
\hline No symptoms, Hojiblanca & August 2005 & Dehesas Frías, Sevilla & 200 & 0.0 \\
\hline Wilting, Hojiblanca & August 2005 & Dehesas Frías, Sevilla & 200 & 0.0 \\
\hline Wilting, Picudo & August 2005 & Dehesas Frías, Sevilla & 200 & 0.0 \\
\hline No symptoms, Hojiblanca & November 2004 & Dehesas Frías, Sevilla & 100 & 7.5 \\
\hline No symptoms, Picudo & November 2004 & Dehesas Frías, Sevilla & 100 & 27.5 \\
\hline No symptoms, Hojiblanca & November 2006 & Dehesas Frías, Sevilla & 100 & 9.0 \\
\hline \multicolumn{5}{|l|}{ Developing fruit ${ }^{z}$} \\
\hline No symptoms, Verdial Hue & June 2008 & Gibraleón, Huelva & 500 & 0.2 \\
\hline No symptoms, Hojiblanca & August 2004 & Dehesas Frías, Sevilla & 500 & 1.2 \\
\hline No symptoms, Hojiblanca & August 2005 & Dehesas Frías, Sevilla & 500 & 1.4 \\
\hline No symptoms, Picudo & August 2005 & Dehesas Frías, Sevilla & 500 & 0.0 \\
\hline \multicolumn{5}{|l|}{ Shoot $^{\mathrm{y}}$} \\
\hline No symptoms, Hojiblanca & August 2005 & Dehesas Frías, Sevilla & 200 & 0.0 \\
\hline No symptoms, Hojiblanca & November 2004 & Dehesas Frías, Sevilla & 100 & 0.0 \\
\hline No symptoms, Picudo & November 2004 & Dehesas Frías, Sevilla & 100 & 2.5 \\
\hline Wilting, Hojiblanca & November 2004 & Dehesas Frías, Sevilla & 100 & 0.0 \\
\hline Wilting, Picudo & November 2004 & Dehesas Frías, Sevilla & 100 & 10.0 \\
\hline No symptoms-Hojiblanca & November 2006 & Dehesas Frías, Sevilla & 100 & 12.0 \\
\hline
\end{tabular}

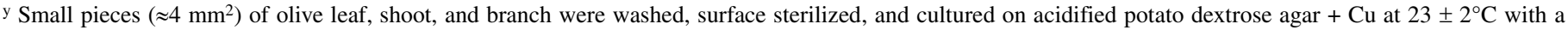
12-h photoperiod of fluorescent light $\left(40 \mu \mathrm{mol} \mathrm{m}^{-2} \mathrm{~s}^{-1}\right)$ for 1 week to isolate Colletotrichum spp.

${ }^{\mathrm{z}}$ Fruit were treated with the Paraquat method and incubated in humid chambers at $23 \pm 2{ }^{\circ} \mathrm{C}$ for 28 days to detect latent infection by Colletotrichum spp. 
Susceptibility of developing fruit. Artificial inoculation of olive plants indicated that fruit were susceptible throughout the developing season. Disease incidence (\%) and RAUDPC were lower when the inoculation was made during the fruit development stage (from 15 June to 15 August) than when plants with fully developed fruit were inoculated (from 15 September to 15 December). The LSD test showed three homogeneous $(P=0.05)$ groups (Fig. 2). Nonlinear regression (negative exponential curve) significantly $\left(R^{2}=0.992\right)$ described the relationship between latent period (in days) and days after full flowering (Fig. 3). Three weeks after the development of fruit rot, inoculated plants with mummified fruit showed defoliation, wilting, and dieback of shoots and branches (DB syndrome). In all, $8 \%$ of the inoculated plants died. The fungus did not develop acervuli or conidial masses on inoculated leaves and shoots but was isolated from $8.7 \%$ of leaves and $6.7 \%$ of shoots. In the second trial, the pathogen infected the developing fruit $(\approx 10 \%$ final size) of cvs. Arbequina, Hojiblanca, and Picual but infections remained latent until the onset of ripening, when fruit color changed, which co-occurred during the fall-winter. Inoculated and control plants of the three cultivars showed a natural drop of developing fruit, and $C$. $a c u-$ tatum did not have a significant (paired $t$ test; $P>0.05$ ) effect on fruit drop (Fig. 4). However, inoculated fruit with anthracnose symptoms fell easily during the fall-winter because the pathogen had infected the fruit peduncle. Cv. Arbequina had significantly $(P=0.001)$ less DB than cvs. Hojiblanca and Picual, which were equally susceptible to the pathogen. Only Hojiblanca showed dead plants (14\%) 9 months after inoculation. There was no significant correlation between the number of mummified fruit and DB severity (data not shown). The incidence of affected fruit increased linearly with fruit ripening for the three cultivars (Fig. 4).
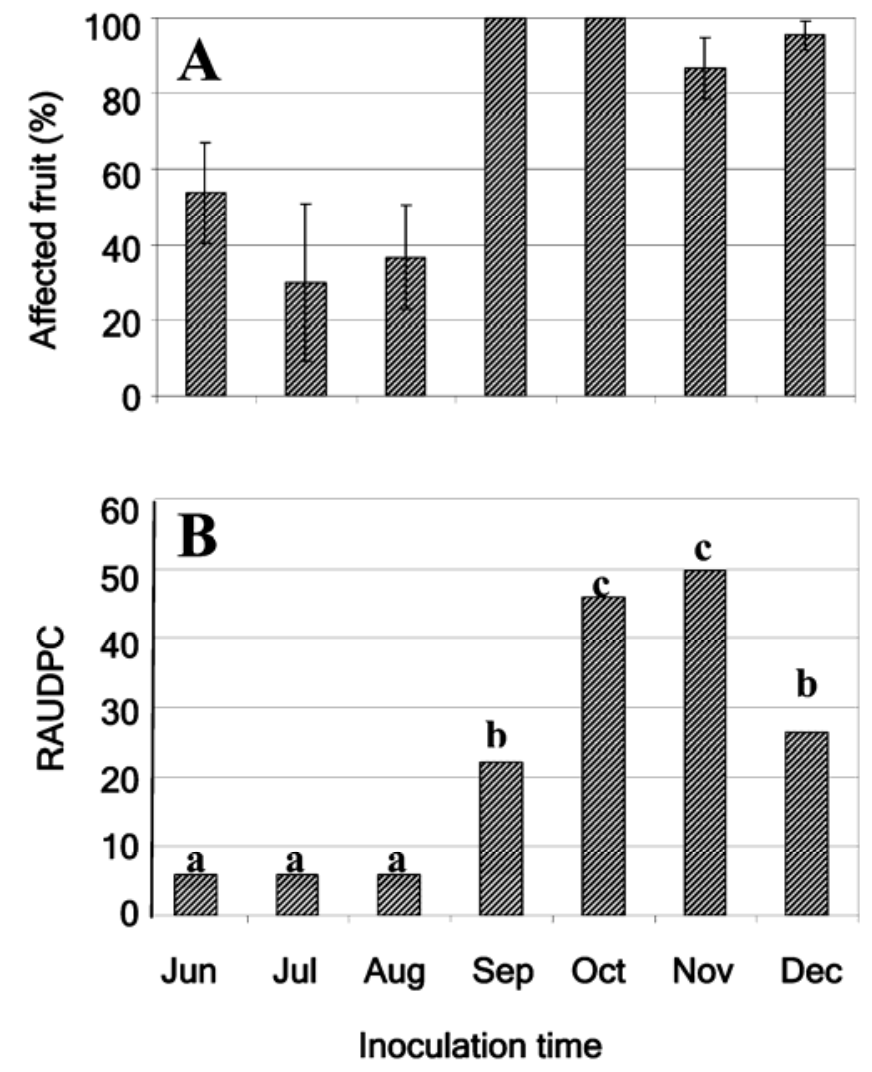

Fig. 2. A, Affected fruit (\%) and B, relative area under the disease progress curve (RAUDPC) in olive plants of cv. Hojiblanca inoculated monthly with Colletotrichum acutatum. Values are the mean of 10 inoculated plants. A, Bars represent the standard error of the mean. B, For each inoculation time, bars with the same letter are not significantly different according to Fisher's protected least significant difference at $P=0.05$.
Comparison between linear regression lines did not show significant $(P>0.05)$ differences among cultivars (data not shown). The pathogen was isolated from $\approx 2 \%$ of the inoculated leaves and shoots of cvs. Hojiblanca and Picual but was not isolated from Arbequina. When inoculated and asymptomatic fruit were treated with Paraquat, the percentage of fruit with anthracnose symptoms was 67, 81, and 50\% for cvs. Arbequina, Hojiblanca, and Picual, respectively.

Susceptibility of inflorescences. $C$. acutatum was highly virulent to olive inflorescences and blighted most of them. The first symptoms were observed 5 days after inoculation. Symptoms in both experiments ranged from collapse of the entire inflorescences to, less frequently, necrosis of ovaries or closed flower buds. In the first trial, all inoculated plants had one fruit $(\mathrm{FS}=$ $0.5 \%$ ), whereas the control plants showed an FS of $17 \%$. These fruit showed latent infection of $C$. acutatum. The pathogen was isolated from $88 \%$ of blighted inflorescences 10 days after inoculation. In the second experiment, $C$. acutatum blighted most inflorescences of cvs. Arbequina, Hojiblanca, and Picual. The pathogen had a significant negative effect $(P>0.05)$ on the AUFSC (data not shown) and on the FS and the number of fruit per plant at the end of the experiment (Fig. 5). Inoculated plants of cv. Arbequina did not have any fruit. Inoculated and control plants showed natural drop of nonfertilized ovaries and developing fruit. C. acutatum was isolated from $>73 \%$ of the blighted inflorescences of the three cultivars 10 days after inoculation. However, it was not isolated from leaves or shoots when the experiment was terminated $\approx 8$ months later. Most inoculated fruit showed typical anthracnose symptoms during ripening and $>90 \%$ of nonsymptomatic fruit showed latent infection by $C$. acutatum.

Natural infection of inflorescences, developing fruit, leaves, shoots, and branches. C. acutatum was isolated from different olive tissues during different years and times, except from dead branches of $>3 \mathrm{~cm}$ in diameter that had a brown-violet discoloration. In general, the pathogen was isolated from a lower percentage ( 0 to $27.5 \%$ ) of leaf, shoot, and developing fruit tissues. Higher values were obtained from asymptomatic or symptomatic leaves and shoots whereas lower percentages corresponded to developing fruit $(<1.5 \%)$ (Table 1$)$. Conidiomata (acervuli) and conidial masses were observed only on fruit treated with Paraquat after incubation in humid chambers for 3 weeks. Conidiomata or conidial masses were not detected on leaves, shoots, and branches showing anthracnose symptoms.

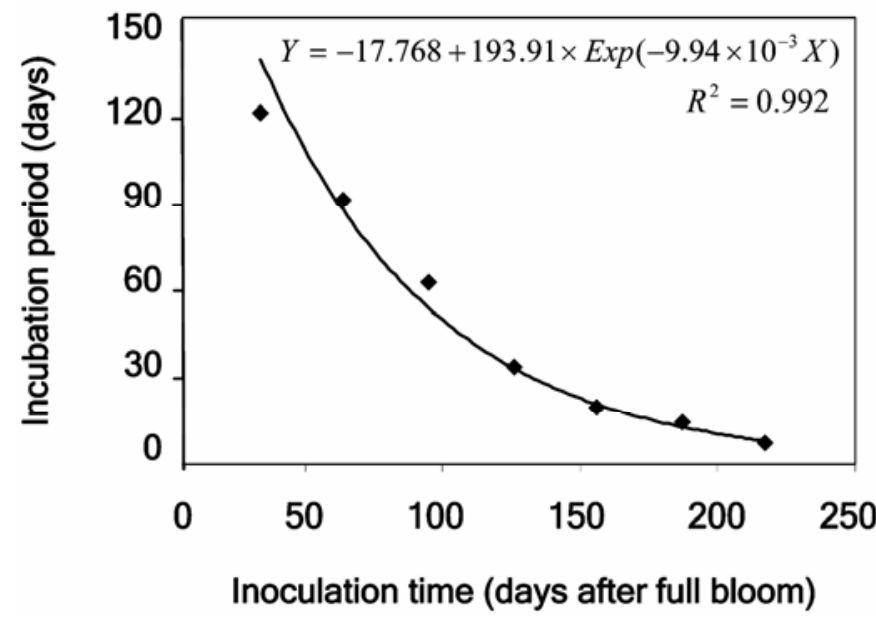

Fig. 3. Relationship between incubation period (in days) and inoculation time (days after full bloom) on olive plants of cv. Hojiblanca inoculated with Colletotrichum acutatum. Values are the mean of 10 inoculated plants. The line demonstrates the fit between the nonlinear model and experimental data calculated by the Levenberg-Marquardt-Nash algorithm. 
Toxicity of cultural filtrates. In the first trial, only stem cuttings of cv. Hojiblanca showed symptoms when treated with a conidial suspension or the sterile filtrate of $C$. acutatum. Severity of symptoms was higher with the sterile filtrate than with the conidial suspension of the pathogen with disease severity values of 1.2 and 2.1, respectively. In the second trial, both cultivars were affected and there was a significant $(P>0.05)$ effect of cultivars, treatments, and their interaction. Stem cuttings of cv. Picual showed mild symptoms in all treatments, although there were no significant differences among treatments 14 days after inoculation. However, stem cuttings of cv. Hojiblanca showed chlorosis and wilting of leaves and most of them died when they were treated with a conidial suspension or sterile filtrate of $C$. acutatum (Table 2).

\section{DISCUSSION}

Olive anthracnose has been traditionally called "aceituna jabonosa" ("soapy olive") in Spanish. This name refers to one of two disease syndromes characterized by a fruit rot with abundant
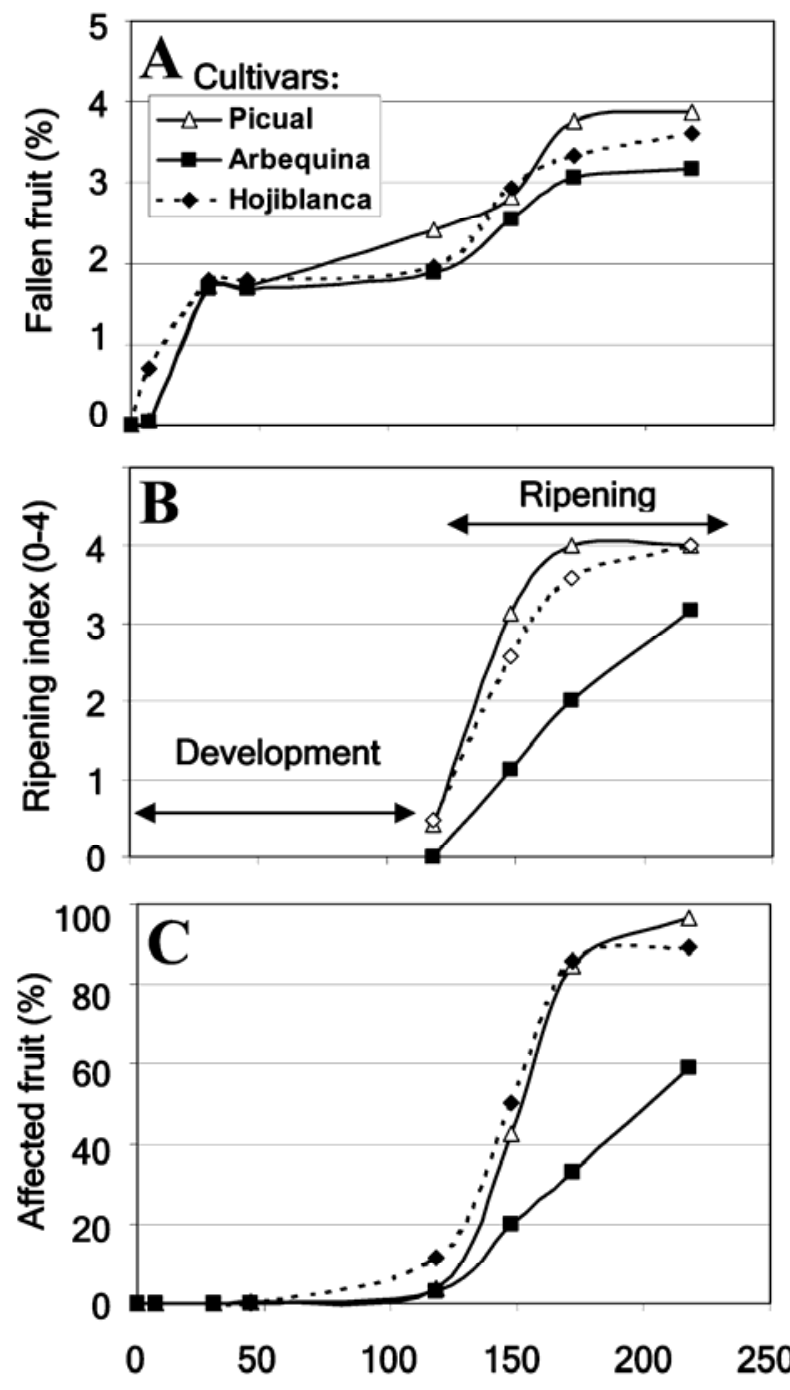

Days after inoculation

Fig. 4. Fallen fruit (\%), ripening index (0-4), and affected fruit (\%) in olive plants of cvs. Arbequina, Picual, and Hojiblanca inoculated with Colletotrichum acutatum during June (fruit $\approx 5 \mathrm{~mm}$ in diameter). A and B, Each point represents mean values of 14 control and 14 inoculated plants because there was no significant effect (paired $t$ test; $P>0.05$ ) of treatments. C, Each point represents mean values of 14 inoculated plants. production of conidia in a gelatinous matrix. The second disease syndrome, leaf wilting and dieback of shoots and branches, is well known in Greece, Italy, and Portugal $(17,25,33,51,57)$ but had never been reported in Spain before the beginning of this research on olive anthracnose $(53,54)$. Our results demonstrate that $C$. acutatum causes both disease syndromes under field and controlled conditions. This is the first report of the branch dieback symptoms associated with olive anthracnose in Spain. Previous work on this disease in Spain reported wilting and drying of branches in olive trees affected by anthracnose under field conditions; however, this syndrome was not associated with anthracnose disease but, instead, was related to water-saturated soils (37).

Olive anthracnose is caused by $C$. acutatum and C. gloeosporioides $(35,36,51)$. In this work, all isolates used were identified as $C$. acutatum and are representative of Andalusia populations of the pathogen (30). However, isolates exhibited some
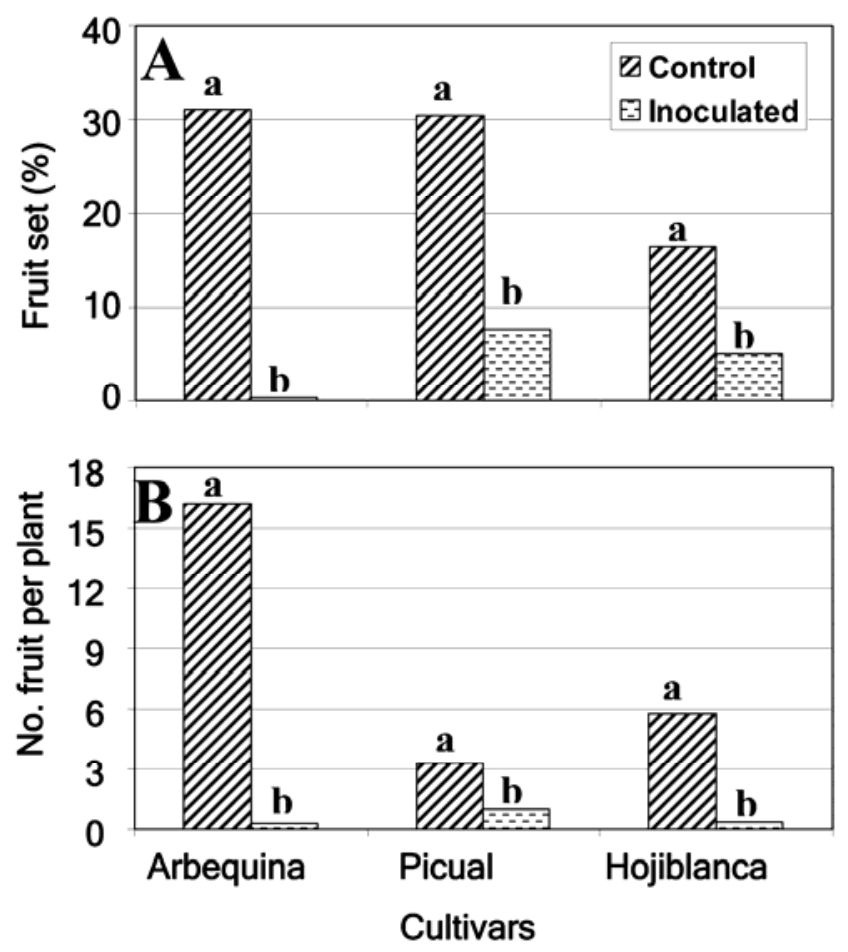

Fig. 5. A, Fruit set (\%) and B, number of fruit per olive plant at 261 days after inoculation. Plants were inoculated with Colletotrichum acutatum during full flowering. Fruit set (FS) was calculated as FS $=$ number of fruit at 261 days after inoculation/total number of initial inflorescences $\times 100$. For each cultivar, bars with the same letter are not different according to the Wilcoxon signed rank test at $P=0.05$.

TABLE 2. Severity of leaf symptoms in olive stem cuttings incubated in several liquid media

\begin{tabular}{lcc}
\hline & \multicolumn{2}{c}{ Cultivar $^{\mathrm{z}}$} \\
\cline { 2 - 3 } Liquid medium $^{\mathrm{y}}$ & Hojiblanca & Picual \\
\hline Sterile water & $0.1 \mathrm{c}$ & $0.0 \mathrm{a}$ \\
Potato dextrose broth & $1.2 \mathrm{~b}$ & $0.2 \mathrm{a}$ \\
Conidial suspension of C. acutatum & $4.0 \mathrm{a}$ & $0.8 \mathrm{a}$ \\
Sterile filtrate of $C$. acutatum & $4.0 \mathrm{a}$ & $1.2 \mathrm{a}$ \\
\hline
\end{tabular}

y Olive stem cuttings with five pairs of leaves were incubated in test tubes with four liquid media for 14 days. Sterile water was the common component of all media. Conidial suspensions $\left(10^{6} \mathrm{conidia} / \mathrm{ml}\right)$ and sterile filtrate of Colletotrichum acutatum were obtained from isolate Col-9 grown on potato dextrose agar and potato dextrose broth, respectively.

${ }^{\mathrm{z}}$ Severity of leaf wilting symptoms was assessed using a 0 -to- 4 scale $(0=$ no symptoms; $4=$ completely wilted). For each cultivar, mean values with the same letter are not significantly different according to Kruskal-Wallis test at $P=0.05$. 
differences in morphology and virulence, indicating that these pathogen populations are not uniform.

Inoculations of young olive plants without fruit and detached leaves demonstrated that stem and leaf tissues can be infected by C. acutatum but the pathogen does not induce anthracnose symptoms. Only the very young shoots of some plants showed a slight apical necrosis but affected plants recovered 2 months after inoculation. These results agree with the lack of symptoms in olive plants inoculated with isolates of $G$. olivarum (subsequently reclassified as C. gloeosporioides) in Portugal (16), Italy (18), Greece (57), and Spain (37), which led to the hypothesis that the anthracnose fungus was specialized in olive fruit $(32,37)$ or that leaves must be in a specific physiological state before they become susceptible to the fungus (57). Field observations in southern Italy $(24,33,49)$, Greece (57), and Portugal (8) showed that the pathogen could be isolated from affected stem and leaf tissues. Even fungal conidiomata were observed on naturally infected and inoculated leaves $(34,49,57)$. These observations led to the general acceptance that the anthracnose pathogen can infect and cause symptoms on leaves and branches in addition to causing fruit rot $(17,25)$. However, in Spain, Mateo-Sagasta considered the fungus to be specialized on olive fruit only (37). Recently, we observed that leaf wilting and branch dieback were common symptoms of anthracnose in several olive cultivars (38), although fungal acervuli or conidial masses were not detected on affected tissues under field conditions (J. Moral and A. Trapero, unpublished data). In bitter rot of apple caused by $C$. acutatum and $C$. gloeosporioides, all isolates of $C$. acutatum and some isolates of C. gloeosporioides caused only fruit rot, whereas other isolates of C. gloeosporioides caused fruit rot and leaf spot (22).

Comparative inoculations of olive plants with and without fruit demonstrated that fruit are required for development of anthracnose symptoms. Only olive plants with affected fruit developed the leaf wilting and branch dieback syndrome several weeks or months after fruit rot. Severity of these symptoms was related to the number of affected fruit, and plants showing a great number of rotten fruit died 3 months after inoculation. The cv. Hojiblanca was more susceptible than Picual to both syndromes, confirming field observations (38). These results, together with the low level of pathogen isolation from affected leaves and branches, suggested that a toxic substance produced on rotten fruit may account for the leaf wilting and branch dieback symptoms. A toxic substance produced by G. olivarum, named Aspergillomarasmin $\mathrm{B}$, was the first report of a phytotoxin produced by a fungal plant pathogen (9), although its role in olive anthracnose was not studied. Our experiments have shown that sterile extracts of $C$. acutatum caused wilting and death of unrooted olive cuttings, confirming the hypothesis that a toxic substance is responsible for the leaf wilting and branch dieback syndrome. Hojiblanca and Picual also differed in their susceptibility to fungal extracts, with Hojiblanca being more susceptible than Picual, similar to what occurs under field conditions (38). The role of phytotoxins in olive anthracnose is unknown. However, they may be important because wilting and dieback symptoms have been associated with a high incidence of fruit rot $(17,25,53)$.

Species of Colletotrichum can affect the flowers and inflorescences of different crops $(7,52)$. Susceptibility of olive flowers to Colletotrichum spp. has not been considered in the pathogenesis of this disease except for one report in South Africa (23). Infection in this case was said to be caused by a special strain of the pathogen, different from the typical $G$. olivarum, which was identified as $G$. fructigenum f. sp. chromogenum (23). Our results demonstrated that $C$. acutatum could infect intact flowers and cause blight of inflorescences (blossom blight). Under very favorable controlled conditions, the pathogen was able to destroy all inflorescences in some cultivars. However, under favorable weather conditions in an olive orchard severely affected by anthracnose, the percentage of inflorescences affected by the pathogen was 1 and 3\% in 2006 and 2007, respectively. This low percentage of infection, together with the high natural flower abortion $(\approx 97 \%)$ in olive cultivars (45), makes it difficult to detect the affected inflorescences in the field and may account for the lack of reports on flower infection by Colletotrichum spp. in olive. In years with low flowering and high incidence of anthracnose, the loss of flowers caused by Colletotrichum spp. might also decrease fruit set.

Under controlled conditions, we observed differences in susceptibility of olive cultivars to blossom blight. All three cultivars inoculated were susceptible; Arbequina was the most susceptible and there was no difference between Hojiblanca and Picual. Susceptibility to blossom blight does not appear to be related to anthracnose resistance of cultivars, because Hojiblanca is susceptible, Arbequina moderately susceptible, and Picual resistant in the field (38). However, this conclusion is based only on artificial inoculations and there are no data on flower susceptibility in the field.

Inoculation of olive flowers also revealed a secondary effect. Most fruit that developed from plants inoculated in the flowering stage were infected. Infection remained latent from May to November, at which time fruit started to show the fruit rot syndrome. Flower infection may play a very important role as initial inoculum (first infected fruit) for the autumn-winter epidemics, besides the low level of natural infection. We have observed that only one infected fruit per tree can result in $100 \%$ of affected fruit in a susceptible cultivar if favorable weather conditions persist during autumn. Although most fruit were rotted in this experiment, plants did not show wilting and dieback of branches, probably due to the low number of affected fruit per plant.

Inoculation of fruit at different times from fruit set until ripening has shown that the pathogen can infect the fruit at all development stages. However, young fruit infection remained quiescent until the onset of ripening in late October or November; therefore, the latent period is related inversely to the time of inoculation (number of days from flowering up to inoculation). When inoculated plants were assessed 1 month after the first symptoms appeared, disease incidence was lower in inoculated plants with green fruit (June to August) than in plants inoculated later (September to December). However, in the second trial, when plants were assessed over several months, fruit rot and mummification occurred in all inoculated fruit. Most plants with mummified fruit later developed wilting and dieback symptoms, although this response was erratic and there were no differences among cultivars, probably due to the low number of fruit per plant. Infection of developing or green olive fruit has been reported previously $(5,21,25,41)$. These authors also showed the difficulty of infecting these fruit (41) and the latency of infections $(21,25)$. Recently, Moral et al. (39) demonstrated that fruit susceptibility increases with increasing fruit ripening, as has been reported in other hosts. The greater susceptibility of mature fruit may be related to the loss of one or several host resistance mechanisms that are present in young, immature fruit $(26,44)$. Although these resistance mechanisms have not been studied in olive anthracnose, it has been suggested that higher concentrations of phenolic compounds in immature olive fruit may account for their resistance to several pests and diseases (47).

Infected fruit may serve as an inoculum source for autumn epidemics, which has been mentioned earlier with regard to flower infection. However, green fruit have lesser probability than flowers to become infected because green fruit infections have to occur during the dry and hot summer, characteristic of the Mediterranean climate, whereas flower infection takes place in the spring (May), when weather conditions (mainly rains) are favorable for infection.

Isolation of $C$. acutatum from leaves and shoots collected in the field at various times confirmed the presence of the pathogen, suggesting that these tissues also may serve as sources of inocu- 
lum for anthracnose epidemics (25). Our results show that the level of infection in these tissues is low, usually $<3 \%$ of sampled tissues during summer-autumn, and that their importance as sources of inoculum is most likely low because acervuli or conidial masses have never been observed under field conditions in Spain. In anthracnose diseases of other hosts, the primary production of conidia is in acervuli, although $C$. acutatum is also capable of developing secondary conidia on the surface of living leaves (29). Therefore, mummified fruit remaining in the tree canopy might be the main source of conidia for infections, similarly to that described for almond anthracnose (1).

Results of this study contribute to a new knowledge of the pathogenesis and disease cycle of olive anthracnose in Spain and other countries. The importance of infected flowers and young fruit as inoculum sources for anthracnose epidemics, as well as the realization that leaf wilting and branch dieback is a secondary disease syndrome that results from fruit infection, involve important changes in the disease cycle of olive anthracnose. These changes must be considered in the future to design a better strategy for the integrated control of this important olive disease.

\section{ACKNOWLEDGMENTS}

This research was funded by the Spanish Ministry of Education and Science (project AGL2004-7495 co-financed by the European Union FEDER Funds). We thank the Spanish Agency for International Cooperation (AECI) for granting Rodrigues de Oliveira a stay at the University of Córdoba for 3 years; F. Luque for her skillful technical assistance in the laboratory; and L. Rallo, D. Prusky, W. J. Kaiser, and T. J. Michailides for critical review of the manuscript.

\section{LITERATURE CITED}

1. Adaskaveg, J. E., and Förster, H. 2000. Occurrence and management of anthracnose epidemics caused by Colletotrichum species on tree fruit crops in California. Pages 317-336 in: Colletotrichum: Host Specificity, Pathology, and Host-Pathogen Interaction. D. Prusky, S. Freeman, and M. B. Dickman, eds. American Phytopathological Society Press, St. Paul, MN.

2. Agosteo, G. E., Macri, C., and Taccone, P. 2005. Susceptibility of olive cv. Itrana to anthracnose. J. Plant Pathol. 87:287.

3. Agosteo, G. E., Macri, C., Faedda, R., Pennisi, A. M., Cacciola, S. O., and Magnano di San Lio, G.. 2003. Epidemic outbreaks of olive anthracnose in central Italy. J. Plant. Pathol. 85:280.

4. Agosteo, G. E., Magnano di San Lio, G., Cacciola, S. O., and Frisullo, S. 2002. Characterisation of the causal agent of olive anthracnose in southern Italy. Acta Hortic. 586:713-716.

5. Agosteo, G. E., and Pennisi, A. M. 1994. Confronto tra isolati di Colletotrichum gloeosporioides ottenuti da olivo e da agrumi in Calabria. Micol. Ital. 1:76-80.

6. Agostini, J. P., and Timmer, L. W. 1992. Selective isolation procedures for differentiation of two strains of Colletotrichum gloeosporioides from citrus. Plant Dis. 76:1176-1178.

7. Arauz, L. F. 2000. Mango anthracnose: economic impact and current options for integrated management. Plant Dis. 84:600-611.

8. Azevedo A. R. 1976. A defesa sanitaria da oliveira em Portugal. Instituto Nacional de Investigação Agrária, Oeiras, Portugal.

9. Ballio, A., Bottalico, A., Bounocore, V., Carilli, A., Di Vittorio, V., and Graniti, A. 1969. Production and isolation of aspergillomarasmin B (lycomarasmic acid) from cultures of Colletotrichum gloeosporioides (Gloeosporium olivarum). Phytopathol. Mediterr. 8:187-196.

10. Barranco, D. 2008. Variedades y patrones. Pages 65-92 in: El Cultivo de Olivo. D. Barranco, R. Fernández-Escobar, and L. Rallo, eds. Coedición Junta de Andalucía and Mundi-Prensa, Madrid.

11. Barranco, D., and Rallo, L. 2005. Épocas de floración y maduración. Pages 283-292 in: Variedades de olivo en España. L. Rallo, D. Barranco, J. M. Caballero, C. Del Rio, C. A. Martín, J. Tous, and I. Trujillo, eds. Junta de Andalucía-Consejería de Agricultura y Pesca. Ministerio de Agricultura, Pesca y Alimentación y Mundi-Prensa, Madrid.

12. Bartolini, G., Petruccelli, R., Tindall, H. D., and Menini, U. G. 2002. Classification, Origin, Diffusion and History of the Olive. FAO, Rome.

13. Biggs, A. R. 1995. Detection of infections in apple fruit with Paraquat. Plant Dis. 79:1062-1067.

14. Binyamini, N., and Schiffmann-Nadel, M. 1972. Latent infection in avocado fruit due to Colletotrichum gloeosporioides. Phytopathology
62:592-594.

15. Brown, G. E. 1975. Factors affecting postharvest development of Colletotrichum gloeosporioides in citrus fruits. Phytopathology 65:404409.

16. Cabral, R. V. G. 1941. Notas sobre Gloeosporium olivarum. Agron. Lusit. 3:49-58.

17. Cacciola, S. O., Pane, A., Agosteo, G. E., and Magnano di San Lio, G. 1996. Osservazioni sull' epidemiologia dell'anthracnosi dell'olivo in Calabria. Inf. Fitopatol. 6:27-32.

18. Ciccarone, A. 1950. Considerazioni biologiche e sistematiche sull'agente della «lebbra» delle olive recenttemente osservata nel Leccese. Boll. Staz. Pat. Veg. Roma 5:143-165.

19. de Andrés, F. 1991. Enfermedades y plagas del Olivo. Riquelme y Vargas Ediciones S.L., Jaén, Spain.

20. García-Figueres, F. 1991. Repilos del olivo: ataque al fruto. Phytoma España 25:31-36.

21. García-Figueres, F., Pedret, E., Duatis, J. J., and Marco, V. 1998. Sensibilidad fenológica del olivo a infecciones de Colletotrichum gloeosporioides. Page 193 in: IX Congr. Soc. Española Fitopatol. SEF, Salamanca, Spain.

22. Gonzalez, E., and Sutton, T. B. 2004. Population diversity within isolates of Colletotrichum spp. causing Glomerella leaf spot and bitter rot of apples in three orchards in North Carolina. Plant Dis. 88:1335-1340.

23. Gorter, G.J.M.A. 1956. Anthracnose fungi of olives. Nature 178:11291130.

24. Graniti, A. 1954. La "lebbra delle olive" in Sicilia. Olivicoltura 9:1-5.

25. Graniti, A., Frisullo, S., Pennisi, A.M., and Magnano di San Lio, G. 1993. Infections of Glomerella cingulata on olive in Italy. EPPO Bull. 23:457465.

26. Jeffries, P., Dodd, J. C., Jeger, M. J., and Plumbey, R. A. 1990. The biology and control of Colletotrichum species on tropical fruit crops. Plant Pathol. 39:343-366.

27. Kaul, J. L., and Thakur, R. S. 1985. Incidence of olive anthracnose (Colletotrichum gloeosporioides Penz.) and its correlation with weather conditions. J. Tree Sci. 4:20-34.

28. Latinovic, J., and Vucinic, Z. 2002. Cultural characteristics, pathogenicity and host range of Colletotrichum gloeosporioides isolated from olive plants in Montenegro. Acta Hortic. 586:753-755.

29. Leandro, L. F. S., Gleason, M. L., Nutter, F. W., Jr., Wegulo, S. N., and Dixon, P. M. 2001. Germination and sporulation of Colletotrichum acutatum on symptomless strawberry leaves. Phytopathology 91:513-520.

30. M.A.P.A. 2006. Encuesta sobre superficie y rendimiento de cultivos. Ministerio de Agricultura, Pesca y Alimentación, Madrid.

31. Madden, L. V., Hughes, G., and van den Bosch, F. 2007. The Study of Plant Disease Epidemics. American Phytopathological Society Press, St. Paul, MN.

32. Marras, F. 1962. La «lebbra» delle olive (da Gloeosporium olivarum Alm.) in Sardegna. Note Fitopalogiche per la Sardegna 1, Istituto di Patologia Vegetale, Univ. Sassari.

33. Martelli G. P. 1960. Primo contributo alla conoscenza della biologia di Gloeosporium olivarum Alm. Phytopathol. Mediterr. 1:31-43.

34. Martelli, G. P. 1961. Acervuli of Gloeosporium olivarum on olive leaves. Phytopathol. Mediterr. 1:125-128.

35. Martín, M. P., and García-Figueres, F. 1999. Colletotrichum acutatum and C. gloeosporioides cause anthracnose on olives. Eur. J. Plant Pathol. 105:733-741.

36. Martín, M. P., García-Figueres, F., and Trapero, A. 2002. Iniciadores específicos para detectar las especies de Colletotrichum causantes de la antracnosis de los olivos. Bol. San. Veg. Plagas 28:43-50.

37. Mateo-Sagasta, E. 1968. Estudios básicos sobre Gloeosporium olivarum Alm. (Deuteromiceto Melanconial). Bol. Patol. Veg. Entomol. Agric. 30:31-135.

38. Moral, J., Ávila, A., López-Doncel, L. M., Alsalimiya, M., Oliveira, R., Gutiérrez, F., Navarro, N., Bouhmidi, K., Benali, A., Roca, L., and Trapero, A. 2005. Resistencia a los Repilos de distintas variedades de olivo. Vida Rural 208:34-40.

39. Moral, J., Bouhmidi, K., and Trapero, A. 2008. Influence of fruit maturity, cultivar susceptibility, and inoculation method on infection of olive fruit by Colletotrichum acutatum. Plant Dis. 92:1421-1426.

40. Moral, J., Oliveira, R., Kaiser, W. J., and Trapero, A. 2007. Susceptibility of flowers, fruits, leaves and branches to infection by Colletotrichum species causing olive anthracnose. (Abstr.) Phytopathology 97:S79.

41. Mugnai, L., Surico, G., and Ragazzi, A. 1993. Glomerella cingulata on olive in India: Morphological and pathological notes. EPPO Bull. 23:449455.

42. Oliveira, R. 2003. Etiología y control químico de la Aceituna Jabonosa causada por Colletotrichum spp. Ph.D. thesis, Universidad de Córdoba, Córdoba, Spain.

43. Peres, N. A., Timmer, L. W., Adaskaveg, J. E., and Correll, J. C. 2005. Lifestyles of Colletotrichum acutatum. Plan Dis. 89:784-796. 
44. Prusky, D. 1996. Pathogen quiescence in postharvest diseases. Annu. Rev. Phytopathol. 34:413-434.

45. Rallo, L., and Cuevas, J. 2008. Fructificación y producción. Pages 127162 in: El Cultivo de Olivo. D. Barranco, R. Fernández-Escobar, and L. Rallo, eds. Coedición Junta de Andalucía and Mundi-Prensa, Madrid.

46. Roca, L. F., Moral, J., Viruega, J. R., Ávila, A., Oliveira, R., and Trapero, A. 2007. Copper fungicides in the control of olive diseases. Olea 26:4850.

47. Ryan, D., and Robards, K. 1998. Phenolic compounds in olives. Analyst 123:31-44.

48. Sanz-Cortés, F., Martínez-Calvo, J., Badenes, M. L., Bleiholder, H., Hack, H., Llácer, G., and Meier, U. 2002. Phenological growth stages of olive trees (Olea europaea). Ann. Appl. Biol. 140:151-157.

49. Saponaro, A. 1953. Presenza di Gloeosporium olivarum Alm. sugli organi vegetativi dell'olivo nel Leccese e nel Brindisino. Ann. Sper. Agrar. 7:609-619.

50. Steel, R. G. D., and Torrie, J. H. 1985. Bioestadística. McGraw-Hill, Bogotá, Colombia.

51. Talhinhas, P., Sreenivasaprasad, S., Neves-Martins, J., and Oliveira, H. 2005. Molecular and phenotypic analyses reveal association of diverse
Colletotrichum acutatum groups and a low level of C. gloeosporioides with olive anthracnose. Appl. Environ. Microbiol. 71:2987-2998.

52. Timmer, L. W. 2000. Anthracnose diseases. Pages 21-22 in: Compendium of Citrus Diseases. L.W. Timmer, S. M. Garnsey, and J. H. Graham, eds. The American Phytopathological Society, St. Paul, MN.

53. Trapero, A., and Blanco, M. A. 2008. Enfermedades. Pages 557-614 in: El Cultivo de Olivo. D. Barranco, R. Fernández-Escobar, and L. Rallo, eds. Coedición Junta de Andalucía / Mundi-Prensa, Madrid.

54. Trapero, A., López-Doncel, L. M., and Viruega, J. R. 1998. Los "Repilos" del olivo: etiología, epidemiología y estrategias de control. Phytoma España 102:154-158.

55. Verma, N., MacDonald, L., and Punja, Z. K. 2006. Environmental and host requirements for field infection of blueberry fruits by Colletotrichum acutatum in British Columbia. Plant Pathol. 56:107-113.

56. Yoshida, S., Hiradate, S., Fujii, Y., and Shirata, A. 2000. Colletotrichum dematium produces phytotoxins in anthracnose lesions of mulberry leaves. Phytopathology 90:285-291.

57. Zachos, D. G., and Makris, S. A. 1963. Studies on Gloeosporium olivarum in Greece II: Symptoms of the disease. Ann. Inst. Phytopathol. Benaki 5:128-130. 